\title{
New prospects in geomorphological and geological mapping of the Rhine-Meuse Delta - Application of detailed digital elevation maps based on laser altimetry
}

\section{H.J.A. Berendsen* \& K.P. Volleberg}

The Netherlands Centre for Geo-Ecological Research (ICG), Department of Physical Geography, Faculty of Geosciences, Utrecht University, PO Box 80115, 3508 TC Utrecht, the Netherlands.

Corresponding author. Email: h.berendsen@geo.uu.nl

Manuscript received: January 2006; accepted: November 2006

\begin{abstract}
Over the past 80 years, the Rhine-Meuse delta has been mapped extensively by drilling boreholes. These maps are compared with a new detailed digital elevation map of the Netherlands (AHN) that became available in 2004 and is based on very accurate, (sub-decimeter) laser-altimetry data. Examples show, that existing maps can be significantly improved. However, field checks remain a necessity. Therefore, the AHN-data need to be confronted with existing borehole descriptions using a GIS. Geomorphological analysis and geological interpretation of surface elevation patterns now enable us to map larger areas, in greater detail, with greater accuracy, and much faster. It is argued that detailed $(\geqslant 1: 50,000)$ geological mapping of the Netherlands should be resumed, combining the databases of Utrecht University, the National Geological Survey and Alterra.
\end{abstract}

Keywords: geomorphology, Holocene geology, Rhine-Meuse delta, laser-altimetry, AHN, LIDAR-DEMS

\section{Introduction}

Over the past 80 years, the Rhine-Meuse delta has been extensively mapped, mainly by collecting borehole data. Surprisingly, aerial photographs and remote sensing so far never played an important role in geomorphological mapping in the Rhine-Meuse delta. The reason is that in this area, elevation differences and geomorphological features are too small to clearly show up on aerial photographs. In addition, the area has been so intensively influenced by human activities that natural landscape elements can hardly be recognized. In 2004 however, a detailed digital elevation map (AHN = Actueel Hoogtebestand van Nederland) became available for the entire Netherlands (revised version: Rijkswaterstaat-AGI 2005). The AHN is based on very accurate, sub-decimeter laser-altimetry data (LIDAR-DEMS) with an average resolution of one measurement per $8 \mathrm{~m}^{2}$. These data allow to map the geomorphology of large areas in greater detail, fast, and with great accuracy.

It is the aim of this paper to show that the AHN can contribute to produce more accurate geomorphological and geological maps of the Rhine-Meuse delta.
Some examples show how the AHN can be used to enhance geomorphological and geological mapping. The geomorphological map of the Netherlands (scale $1: 50,000$ ) has recently been completed by Alterra (the successor of the Dutch Soil Survey) using the modern technology (Koomen \& Maas, 2005). Using the AHN, and confronting it with borehole data of the National Geological Survey, Alterra, and Utrecht University can be expected to lead to significant improvements of existing maps of the Rhine-Meuse delta.

\section{Historical overview of geological mapping in the Rhine-Meuse delta}

Detailed geological and geomorphological mapping of the Holocene Rhine-Meuse deltaic plain in the Netherlands (Fig. 1) effectively started with the Ph.D. dissertation of Vink (1926). He was the first to recognize that sand, clay and peat did not occur at random, but were related to former fluvial systems, and he mapped channel belts based on the occurrence of sand. The first geological map of the Netherlands, scale $1: 50,000$, supervised by Tesch (1942), was a major step backwards, as it 


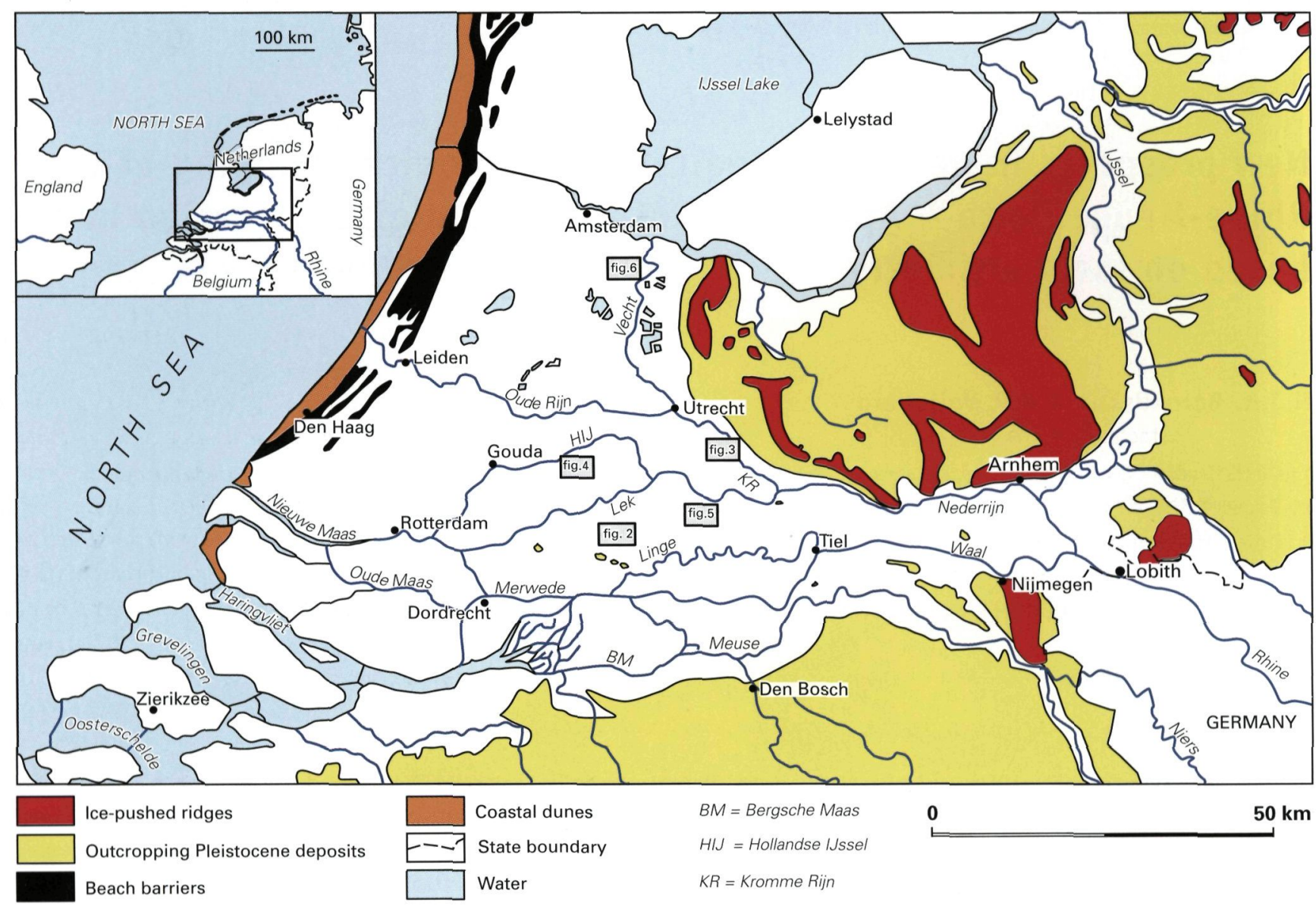

Fig. 1 The Holocene Rhine-Meuse delta in the Netherlands, and location of the Figures 2 through 6.

did not recognize the excellent work of the geographer Vink (1926), and as a result the map showed only isolated 'islands' of sand.

Later, much regional information was obtained from detailed geogenetic mapping (e.g., Edelman et al., 1950; Egberts 1950; Pons, 1957, 1966) by the famous 'Wageningen' school of soil scientists, and maps became more sophisticated. This work was carried forward by Stiboka (1965). After that, the soil science turned away from 'genetic' maps and became presumably more valuable for farming, but contributed less to the understanding of geomorphology and geology. Unfortunately, most of this work was only published in Dutch.

In the period 1960 - 1980 new geological maps, scale 1:50,000 were published, based on a revolutionary 'profile-type legend' developed by Hageman (1963). This allowed to describe and map the entire Holocene sequence and not just the deposits at the surface. Although the spatial resolution and the reliability of the maps (Verbraeck, 1970; Verbraeck, 1984; Bosch \& Kok, 1994) were low due to a low coring density ( 6 corings per $\mathrm{km}^{2}$ ), they provided a good insight into the vertical succession of layers within the Holocene sequence. Unfortunately, the maps were based on some misconceptions leading to confusion about lithostratigraphy and chronostratigraphy, which makes them obsolete by modern standards (Berendsen, 1982, 1984,
2004; De Mulder et al., 2003). The slow progress, in combination with reorganizations and budget cuts of the Geological Survey, changing political notions and associated management decisions unfortunately resulted in termination of the entire mapping project. Almost simultaneously, the geomorphological map of the Netherlands, scale $1: 50,000$ (a common project of the Geological Survey and the Soil Survey) was suspended.

A new concept of geomorphological mapping was introduced by Berendsen (1982), in which lithological successions play an important role in defining geomorphological (or geological) map units. This was partly based on work carried out in the Mississippi delta by Fisk (1947). Since 1973, the Rhine-Meuse delta has been studied in detail by the Utrecht University group of fluvial geomorphologists and sedimentologists (e.g., Berendsen, 1982; Berendsen et al., 1986; Törnqvist, 1993; Weerts \& Berendsen, 1995; Weerts, 1996; Makaske, 1998; Berendsen \& Stouthamer, 2000; Berendsen \& Stouthamer, 2001; Stouthamer, 2001; Berendsen et al., 2002; Cohen, 2003). An important source of information for this work was fieldwork carried out by students of physical geography at Utrecht University under the supervision of the first author. A total of over 200,000 lithological borehole descriptions, $1550{ }^{14} \mathrm{C}$ dates and 36,000 dated archaeological artifacts (collected by the National Service for Archaeological Heritage) have become 
available. A map at a scale of $1: 100,000$ was published showing the ages of the Holocene channel belts (Berendsen \& Stouthamer, 2001). The study of Berendsen \& Stouthamer (2001) presented the first palaeogeographic overview of the entire Holocene delta. In some regions much more detailed information is available, as the $1: 100,000$ map is partly based on original field maps to the scale $1: 10,000$. In other areas, older channel belts that occur at greater depth below the surface (and hence are virtually invisible in the terrain), were taken from the geological map. However, these channel belts were often mapped erroneously. Some of them can now be mapped accurately, because the AHN shows spatial patterns that are not detectable in the field.

In years to come, an effort will be made by Utrecht University to enhance the accuracy of the (digitally available) map of Berendsen \& Stouthamer (2001), so that it can be used at a larger scale. This process will be significantly accelerated by the application of the AHN.

\section{The 'Actueel Hoogtebestand van Nederland' (AHN)}

The second version of the 'Actueel Hoogtebestand van Nederland (AHN)', that is used in this paper, is referred to as Rijkswaterstaat-AGI (2005). The production of the AHN is commissioned by the Directorate General for Public Works and Water Management (Rijkswaterstaat), who also distributes (parts of) the map. The AHN is a detailed digital elevation map of the entire Netherlands based on laser-altimetry measurements from airplanes. It will be updated every two years.

The AHN generally has an average spatial resolution of 1 measurement per $8 \mathrm{~m}^{2}$ and a minimum resolution of 1 measurement per $16 \mathrm{~m}^{2}$ (Van Heerd et al. 2000). In the Holocene Rhine-Meuse delta, the average resolution is 1 measurement per $4 \mathrm{~m}^{2}$. Earlier elevation maps of the Netherlands (based on levelling) in the period 1950 - 1965 have a spatial resolution of only 1 measurement per $10,000 \mathrm{~m}^{2}$, which is generally good enough to show the main channel belts, but too low to show details like bar-and-swale topography or the presence of residual channels and crevasse deposits. Since 1985 these maps have not been updated anymore.

The vertical resolution of the AHN is $1 \mathrm{~cm}$, although the absolute vertical accuracy per point (relative to NAP = Dutch Ordnance Datum) is much less: the standard deviation is on the order of $15 \mathrm{~cm}$ for the first generation AHN (in the second generation this has been improved to $8 \mathrm{~cm}$ ). The standard deviation is mainly due to stochastic laser measurement errors. In addition, systematic errors on the order of $\pm 5 \mathrm{~cm}$ exist due to inaccuracies in the flight path (location, altitude, flight angle), and vegetation effects that need to be removed to obtain 'true' elevations. In general, the accuracy increases with the number of measured points, as does the cost.

\section{Using the AHN}

For geological and geomorphological mapping, relative elevation differences are often more important than absolute elevation. This means, that even cm-scale elevation differences give meaningful information provided they show a spatial pattern. Such small elevation differences are generally not visible in the field, yet they can be a clue to the mapping of older Holocene channel belts that have been covered with peat or clay. In the past, such channel belts were often found in boreholes by chance, and their spatial pattern had to be reconstructed from other boreholes that were placed haphazardly in the surrounding area. This practice often led to erroneous mapping the boundaries of channel belts. The location of the channel belt was drawn in the interval between two boreholes, while the actual location often was somewhere else. Figure 2 shows examples of channel belts that were erroneously connected, and even mapped channel belts that seem not to exist at all.

Accurate mapping always depended on the experience of the field geologist, but there is a limit to what elevation differences humans can see. Because the AHN now enables us to visualize even the slightest elevation differences, this is a great new tool that can help to speed up accurate geomorphological and geological mapping. Some preliminary tests have shown, that in the Alblasserwaard, where peat is abundant, channel belts at a depth of $7 \mathrm{~m}$ below the surface can often still be detected on the AHN. This is the result of significant differential compaction in this area, and may differ in other areas. Of course boreholes are still necessary, but the AHN enables us to determine the locations of channel belts much more effectively.

It is also important to realize that, for geomorphologists, the most recent version of the AHN is not always the most useful one. Increasing obliteration by human interference diminishes the quality of newer images for geomorphological mapping, older images are more likely to show the 'natural' geomorphological features. However, the combination of older and newer AHN images may provide important information about relatively fast processes like peat compaction or compaction due to the extraction of natural gas.

The application of the AHN for geomorphological mapping is not entirely new: in the Netherlands the AHN has been used to complete the Geomorphological Map of the Netherlands (Koomen \& Maas 2005). However, for this map only a limited amount of fieldwork has been carried out. Although the Geomorphological Map of the Netherlands shows many 'new' landforms that remained undetected before the AHN became available, detailed information on their nature is often lacking, due to a lack of field observations.

In archaeological studies, the AHN becomes increasingly important, and has already contributed to the discovery of spectacular new archaeological sites. 

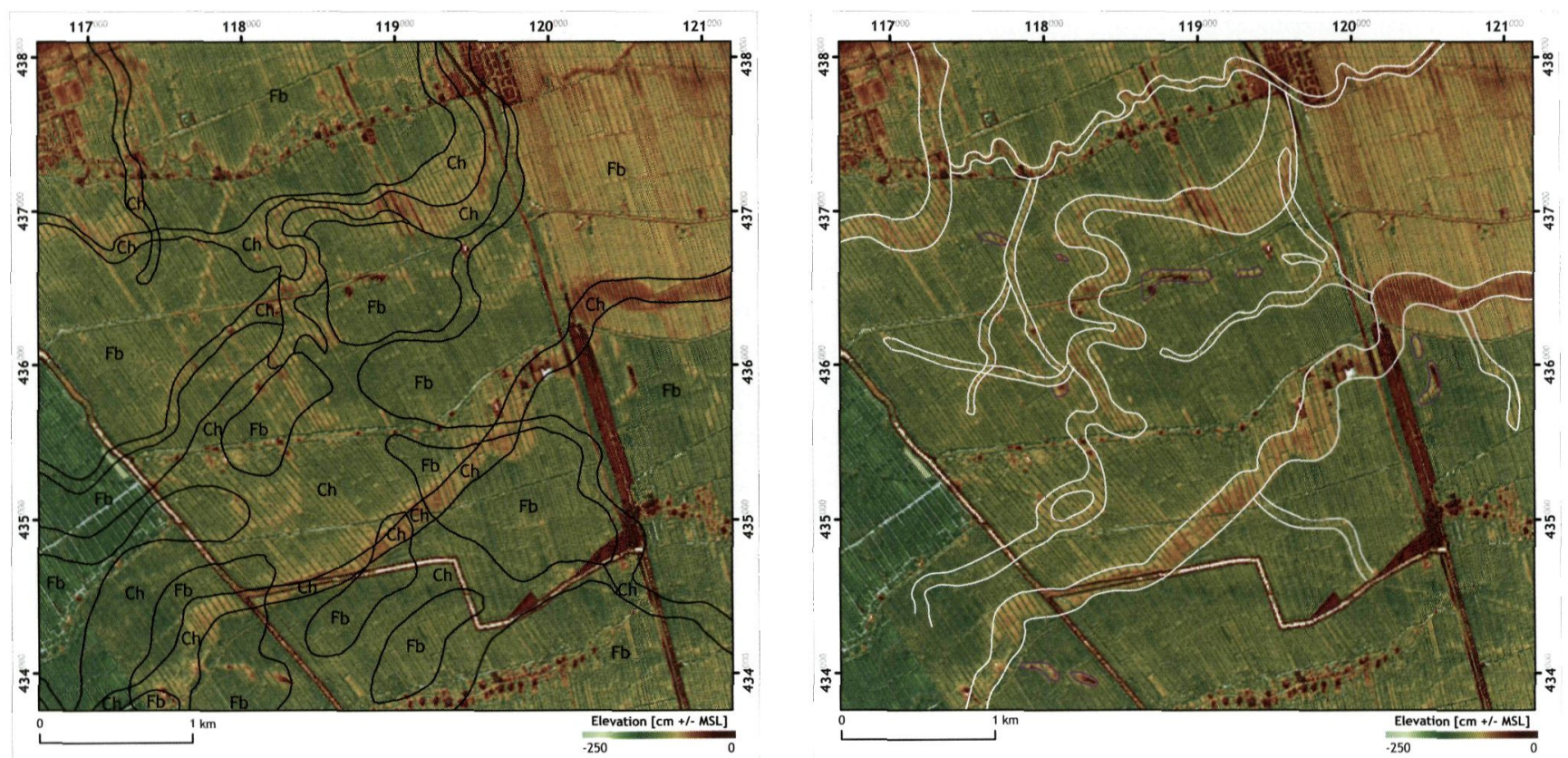

a.

Fig. 2. a. Part of the Alblasserwaard with channel belts according to the geological map $1: 50,000$ of the Netherlands (Bosch \& Kok 1992), indicated in black lines, and b. according to an interpretation (white lines) of the digital elevation map (AHN). Presumed eolian dunes are indicated in purple. In general, channel belts are narrower and more sinuous than indicated on the geological map. Recent channel belts were mapped more accurately than older channel belts that are covered with clay and peat. Although the interpretation of the AHN-image needs to be field-checked, it clearly shows its potential as a mapping tool.

In geological mapping, the potential of the AHN still has to be explored. Detailed geological maps are important for numerous applications, like groundwater (pollution) studies, foundation of infrastructure, compaction, archaeology, gravel, sand and clay mining, etc. The most recent geological map, scale $1: 50,000$, that was unfortunately suspended in the 1990 's, is often not accurate enough for practical applications. Using the AHN in combination with borehole databases of Alterra, Utrecht University and the National Geological Survey to improve the quality of the map may solve that problem. Based on the AHN, a new geological map at a scale of $1: 10,000$ of the entire delta can in principle now be made with a reasonable amount of effort and within a reasonable time frame.

\section{Method}

The AHN $5 \times 5 \mathrm{~m}$ grid-data were imported in ArcMap (ESRI), and an appropriate vertical elevation scale was chosen. This involves omitting tall artificial structures like buildings etc., in order to stretch the maximum number of colours over the minimum elevation difference. The original data has not been changed, but the interval between minimum and maximum values represented by the colour scale has been tightened. When using this method of representation in ArcMap, the program automatically uses a linear interpolation between the minimum and maximum values. This is a trial and error procedure, only based on visual interpretations of the processed image. Thereby we assume that the final elevation range represents the optimal contrast needed for geomorphological analyses. Standard colour schemes from ArcMap were used to represent elevation. The location of boreholes and/or digital maps were added to the GIS. This allowed us to interpret elevation differences in combination with lithology. Subsequently, an evaluation could be made of structures that are and that are not visible in the AHN-image. The examples given below show, that the AHN is a great new mapping tool, that allows to make better maps, in more detail, much faster.

\section{Example 1 - Almost perfect correlation of the AHN and the map of Berendsen (1982)}

Figure 3 shows the AHN of part of the Kromme Rijn area, southeast of Utrecht. The Kromme Rijn river is recognisable as a meandering depression depicted in green. The black lines and codes are taken from Berendsen's (1982) geomorphological map. The green colors in the AHN-image nearly perfectly match with the floodbasins, while yellow and red colors coincide with alluvial ridges. Residual channels are seen as elongated depressions in green or yellow. In general, there is a good correspondence between the map and the AHN. The AHNimage even suggests that some additional residual channels can be distinguished (Fig. 3b), and some can be extended further downstream or upstream. These suggested additions 


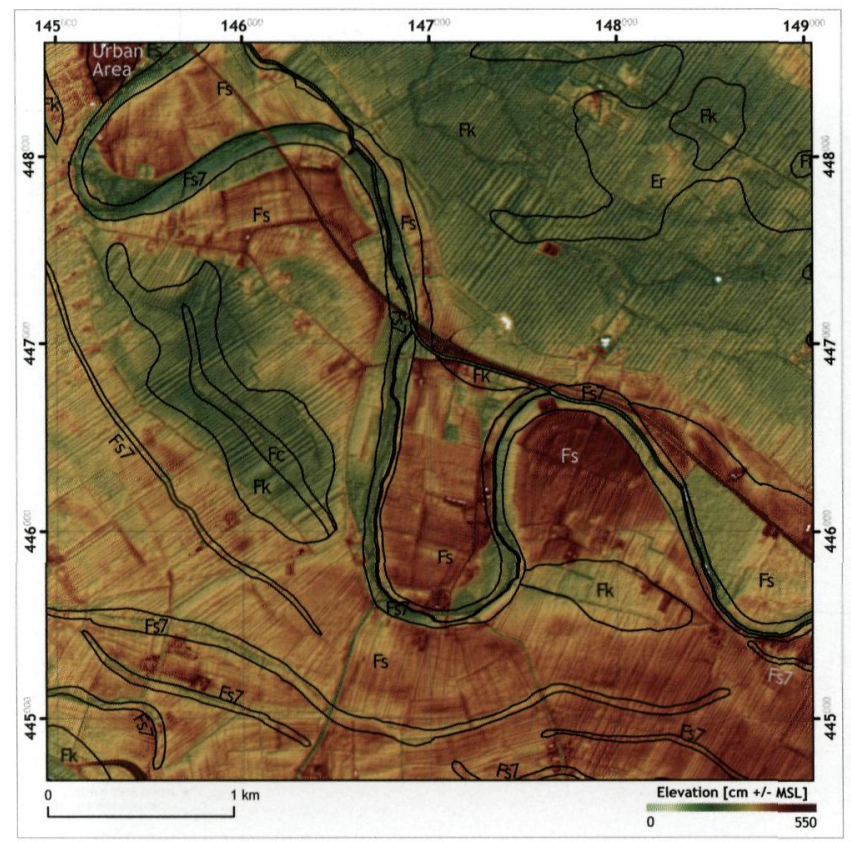

a.

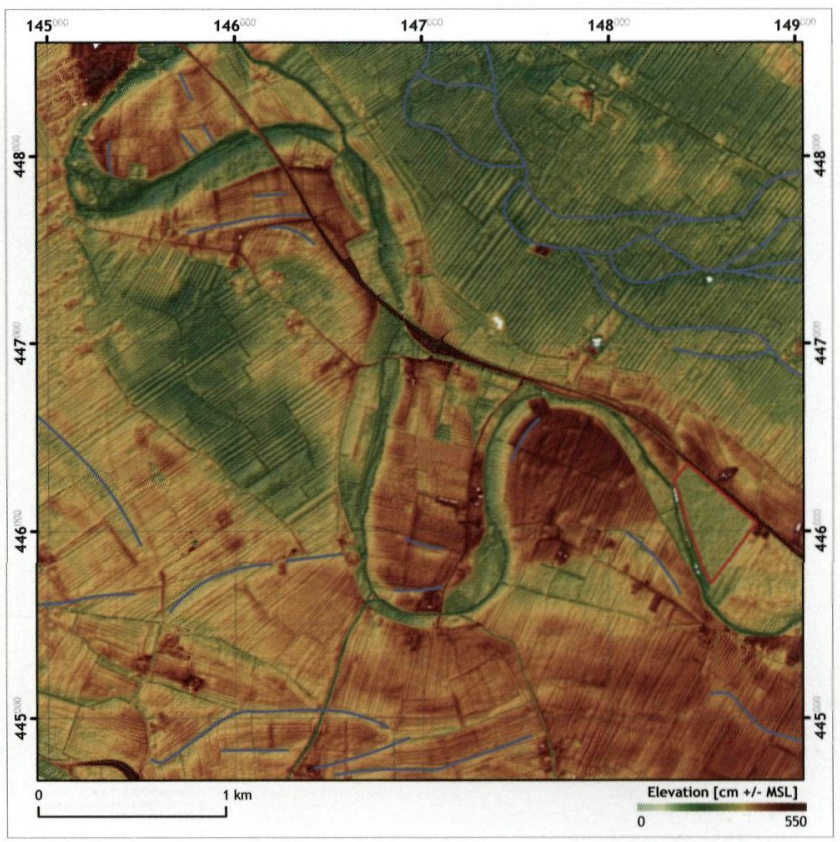

$b$.

Fig. 3. a. AHN of part of the Kromme Rijn area, southeast of Utrecht, compared to Berendsen's (1982) map (black lines). There is a close correspondence between the two maps; $b$. Some additional residual channels (indicated in blue) can be seen in the AHN-image. The codes Fs ... represent alluvial ridges, $F c \ldots$ crevasse splays, Fk ... floodbasins, Ed ... and Er ... are coversand areas. The numbers refer to a description of the lithological succession. The code Fs7 refers to residual channels.

(indicated in blue in Fig. 3b) will have to be checked in the field. On the right hand side of the image a green triangular form marks an area where clay was dug away from the natural levee of the Kromme Rijn. In Fig. 3b this area is enclosed by a red line.

\section{Example 2 - Additional channel belts visible on the AHN}

Figure 4 shows a comparison of the AHN and the map of Berendsen \& Stouthamer (2001) of the area southwest of Montfoort, which is among the most densely drilled areas in the world. In general, there is an excellent correspondence between the map and the AHN-image. Channel belts, residual channels, crevasse splays and many other features shown on the map can also be recognized in the AHN-image. However, it is also clear that an entire meandering channel belt (in the center of the image) with a bifurcation or an avulsion location was missed (indicated with white lines in Fig. 4b). The reason for this is, that in the early years of mapping (when most drillings were carried out in this area), borings were performed to a depth of $2 \mathrm{~m}$ below the surface. Although the coring density was high, the channel belt was missed because its top mostly occurs slightly deeper than $2 \mathrm{~m}$. Later, drillings were deeper (deep borings are indicated by white dots in Fig. 4a), but the coring density was much less, and the spatial pattern of the channel belt could not be established. The east-west cross sections (indicated by blue lines) in the western part of the image were drilled, because a N-S running channel belt was indicated on the geological map by Verbraeck (1970). The cross sections showed that this channel belt does not exist. It was inferred from a few randomly placed borings by the Geological Survey in the two E-W running channel belts that were missed.

The AHN shows spatial patterns that are virtually invisible in the field. The AHN thus makes it easier to find the best coring locations, and often shows details, that are not, or no longer, visible in the field. Hence it saves time, while at the same time helps to produce more accurate maps.

\section{Example 3 - Comparison of the AHN with the map of Verbraeck (1970)}

In Figure 5, an AHN image of the Zijderveld channel belt is shown near the village of Zijderveld. The location of the channel belt on Verbraeck's (1970) map is shown with black lines. The AHN shows clearly, that the Zijderveld channel belt was erroneously mapped by Verbraeck (1970). The interpretation was based on connecting boreholes containing sand, rather than surface morphology. One of these boreholes was located on a Late Glacial eolian dune instead of on the alluvial ridge. The dune is visible in the middle of the non-existing southward sweeping bend (encircled in purple in Fig. $5 \mathrm{~b}$ ).

The corrected map (Fig. 5b) shows the channel belt margins in white lines. Not only the channel belt can be seen in the AHN, but also the residual channel (indicated in blue), which 


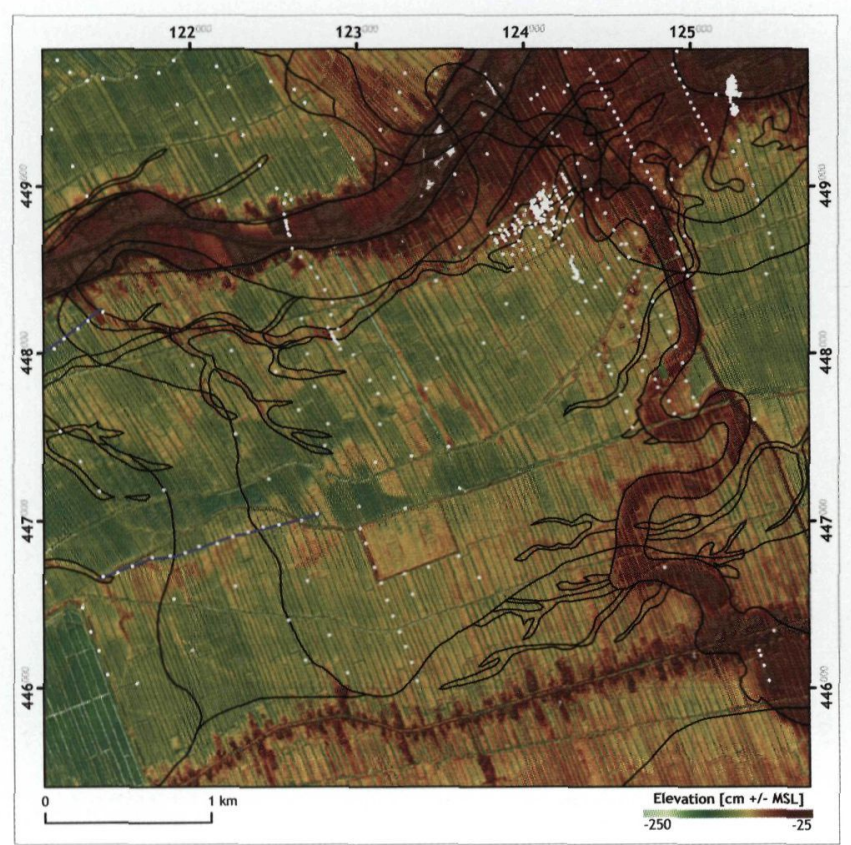

a.

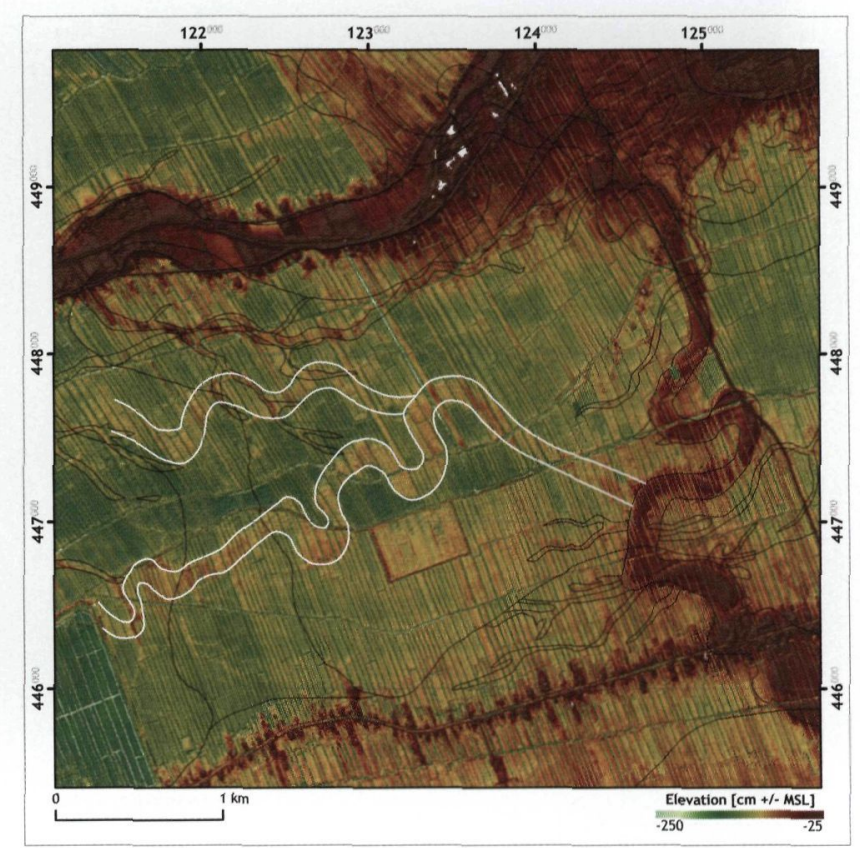

b.

Fig. 4. a. AHN of the Montfoort area, southwest of Utrecht, compared to Berendsen \& Stouthamer's (2001) map (black lines); b. New channel belts, not mapped before, are visible in the central part of the AHN-image (white lines).

is only $20 \mathrm{~m}$ wide. The white rectangle in the eastern part of the image represents the excavations of the National Service for Archaeological Heritage. They indeed found the residual channel in the southeastern part of their excavation.

\section{Example 4 - Applying the AHN in unknown areas}

In areas with little or no field evidence, care should be taken not to overestimate the value of the AHN. Since the AHN is a remote sensing image, ground verification remains an absolute necessity. In Figure 6 part of the Vecht area is shown, just south of Amsterdam.

At first sight, the AHN suggests that there is a wide channel belt (boundaries shown in yellow in Fig. 6b), and possibly a much smaller one with a residual channel, in the northern and eastern part of the image (boundaries shown in white, hypothetical residual channels in blue). This, in itself, seemed strange, because it was known that the area is characterized by very narrow channel belts, encased in peat. Without field information, it proved impossible to interpret the features that are visible on the AHN-image.

Our field studies in 2004 showed, that what seems to be a wide channel belt is actually a former lake, filled up with clastic sediments. The smaller higher areas in the north and east are crevasse channels, being active just before the lake was completely filled in.

\section{Conclusions}

Examples show, that the detailed digital elevation map of the Netherlands (AHN) can be used to enhance geomorphological and geological maps, especially in the Rhine-Meuse delta. Use of the AHN can save a large amount of time, and results in more accurate and more detailed maps. Nevertheless, the AHN should always be used in combination with borehole information and/or other field evidence, to avoid misinterpretations. The AHN proves especially useful for accurately mapping relatively small-scale, and/or irregularly shaped large-scale features that are difficult to map in the terrain, like narrow channel belts, crevasse splays, residual channels or (Late Glacial) eolian dunes.

Because new maps can now be made much faster, geological mapping of the Netherlands at a detailed scale $(\geqslant 1: 50,000)$ should be resumed, and existing spatial databases of the subsurface of various institutes in the Netherlands should be combined and confronted with the new AHN data.

The large amounts of money presently being invested in the infrastructure of the densely populated Rhine-Meuse delta, and the vulnerability of this low lying area, demand a proper management of the subsurface and its resources, which crucially depends on accurate spatial geological data. Given the new developments outlined in this paper, the prospects of realizing a detailed geological map of the shallow subsurface in an efficient and cost-effective way are better than ever before. Therefore, this goal presently deserves a national strategy and funding, and high priority. 


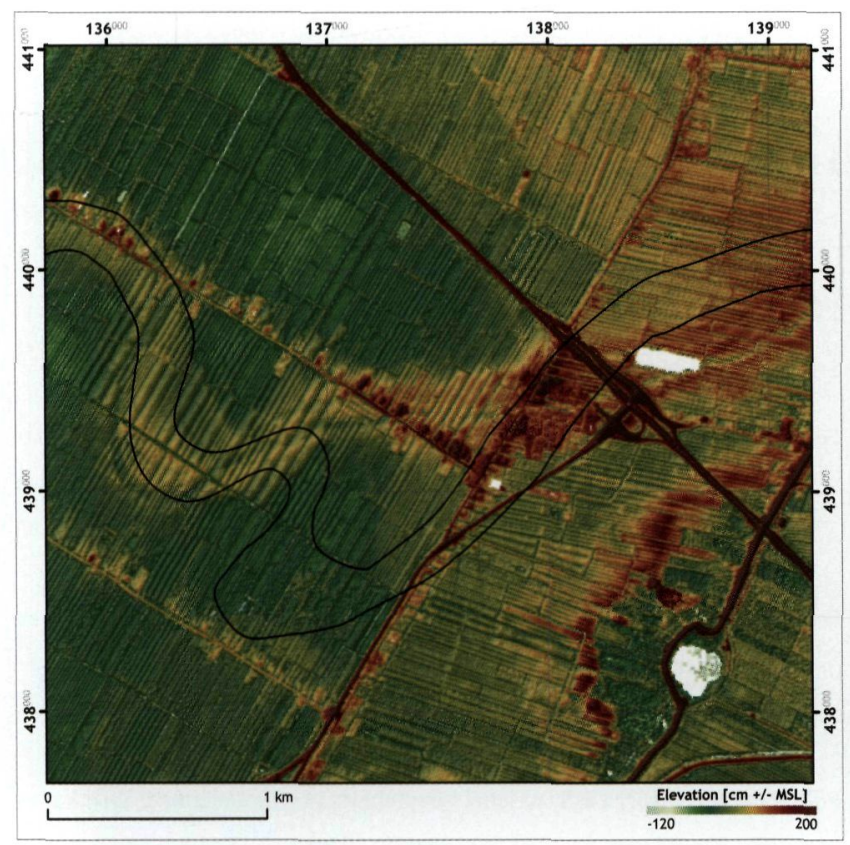

a.

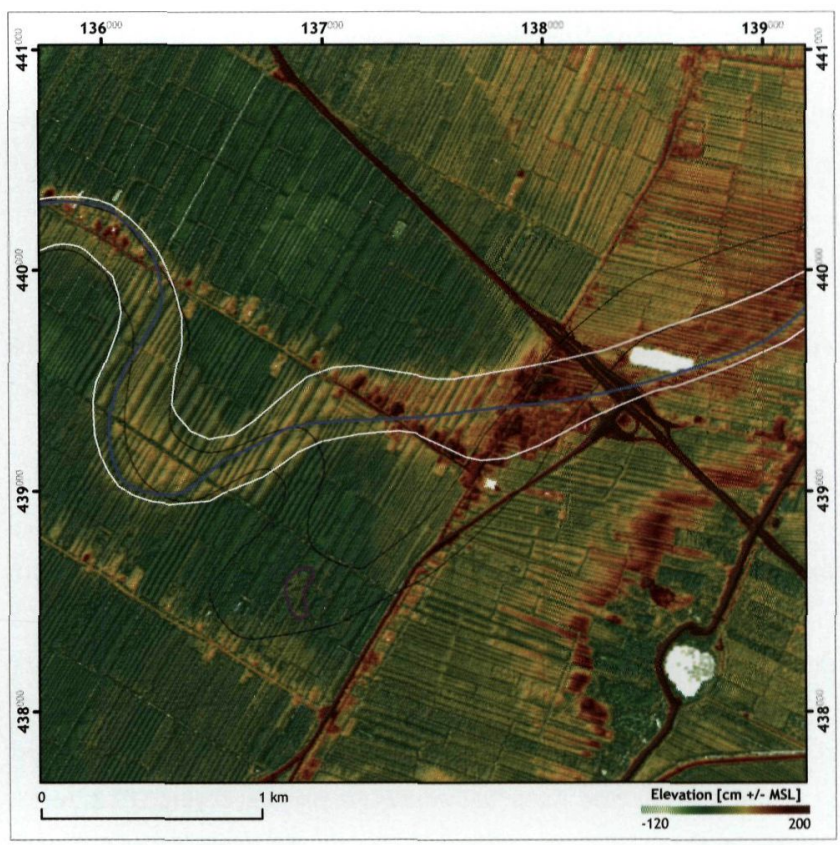

$b$.

Fig. 5. AHN of the Zijderveld channel belt, compared to Verbraeck's (1970) map; a. AHN-image (Rijkswaterstaat-AGI 2005) of the Zijderveld channel belt near Zijderveld. The channel belt is the red-yellow zone meandering from east to west across the image. Thin black lines indicate the location of the Zijderveld channel belt according to the geological map of the Netherlands 1:50,000 (Verbraeck 1970); $b$. The geological map shows a bend south of the true channel belt that clearly does not exist. Within the channel belt the residual channel can be seen as an elongated depression, meandering across the channel belt. White lines indicate the correct location of the Zijderveld channel belt, based on the AHN. The residual channel is indicated by a thick blue line. In the terrain it is visible at some locations, but very difficult to map. For accurate mapping, the AHN data should be combined with borehole information.

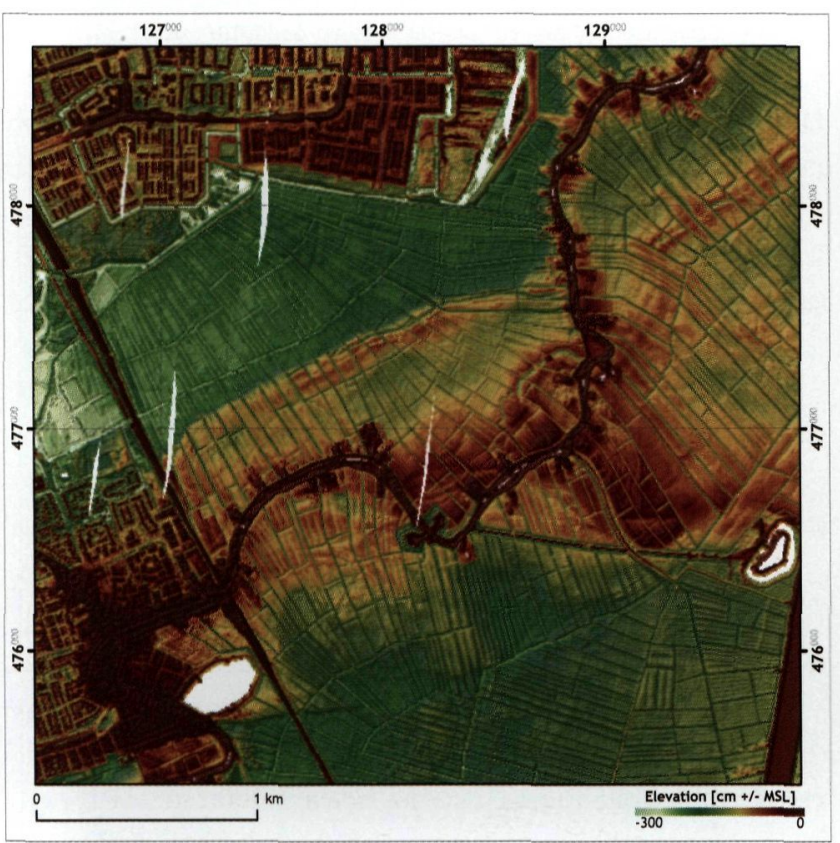

a.

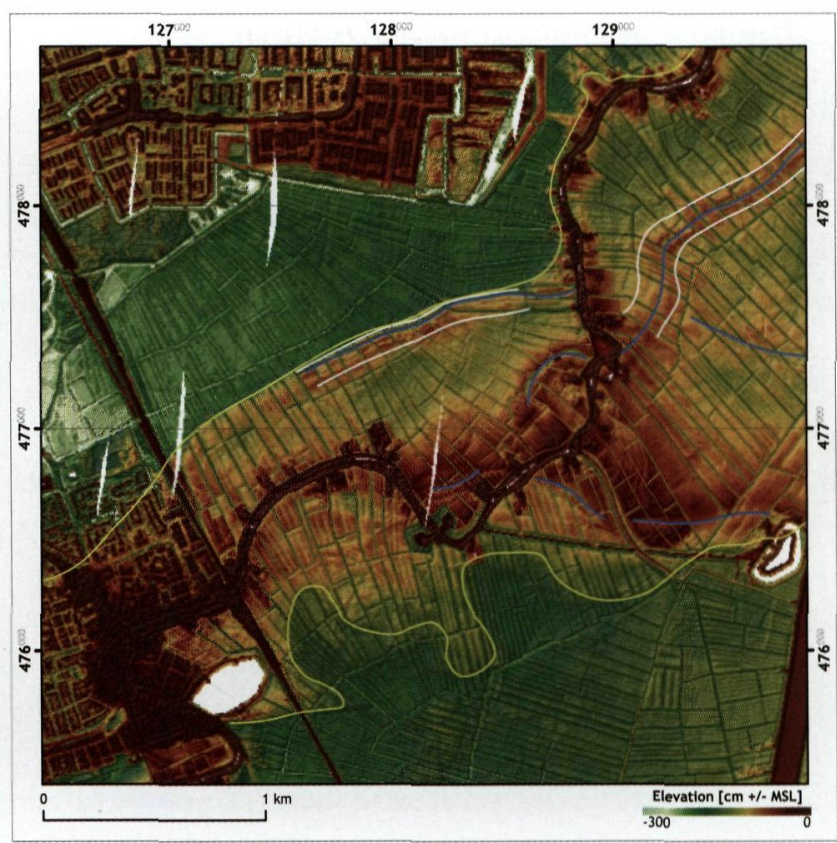

b.

Fig. 6. Part of the Vecht area, south of Amsterdam. The AHN can be misleading without proper field checks. Instead of a wide channel belt, the higher elevated area in the central part of the picture is a filled-in lake, that is now at a relatively high elevation due to differential compaction: the lake fill consists of clastic sediments, while the surrounding areas (in green on the AHN-image) consist of peat. 


\section{Acknowledgements}

We like to thank Bart Makaske and Whitney Autin for valuable comments on an earlier version of this paper.

\section{References}

Berendsen, H.J.A., 1982. De genese van het landschap in het zuiden van de provincie Utrecht, een fysisch-geografische studie. Ph.D. Thesis (with summary in English), Utrechtse Geografische Studies 10, 256 p.

Berendsen, H.J.A., 1984. Quantitative Analysis of Radiocarbon Dates of the Perimarine Area in the Netherlands. Geologie en Mijnbouw 63, pp. 343-350.

Berendsen, H.J.A., (ed.), 1986. Het landschap van de Bommelerwaard. With summary in English. Nederlandse Geografische Studies 10, 184 p.

Berendsen, H.J.A., 2004. Rivers and the sea: how science went wrong explaining the formation of the Netherlands' coastal plain. In: Dietz, T., Hoekstra, P. \& Thissen, F. (eds): The Netherlands and the North Sea. Dutch geography 2000-2004. KNAG: Netherlands Geographical Studies 325, p. 56-63.

Berendsen, H.J.A., 2005. De Laaglandgenese databank. CD-ROM, Department of Physical Geography, Utrecht University.

Berendsen, H.J.A. and Stouthamer, E., 2000. Late Weichselian and Holocene palaeogeography of the Rhine-Meuse delta, the Netherlands. Palaeogeography, Palaeoclimatology, Palaeoecology 161 (3/4): 311-335.

Berendsen, H.J.A. and Stouthamer, E., 2001. Palaeogeographic development of the Rhine-Meuse delta, the Netherlands. Assen: Van Gorcum, $268 \mathrm{p}$.

Berendsen, H.J.A., Faessen, E.L.J.H., Hesselink, A.W. \& Kempen H., 2002. Zand in banen - Zanddieptekaarten van het Gelders Riverengebied met inbegrip van de uiterwaarden. Sand-depth maps of the eastern part of the Rhine-Meuse delta (with a summary in English). Arnhem: Provincie Gelderland, in samenwerking met Rijkswaterstaat, Waterbedrijf Gelderland en Universiteit Utrecht, 53 p. Coloured maps.

Bosch, J.H.A. \& Kok, H., 1994. Toelichtingen bij de geologische kaart van Nederland $1: 50.000$. Blad Gorinchem (Gorkum) West (38W). Haarlem: Rijks Geologische Dienst.

Cohen, K.C., 2003. Differential subsidence within a coastal prism. Late-Glacial - Holocene tectonics in the Rhine-Meuse delta, the Netherlands. Netherlands Geographical Studies 316, 208 pp. KNAG/Faculteit Ruimtelijke Wetenschappen Universiteit Utrecht.

De Mulder, E.F.J., Geluk, M.C., Ritsema I., Westerhoff, W.E. \& Wong, Th.E. 2003. De ondergrond van Nederland. Geologie van Nederland, deel 7. Utrecht. Nederlands Instituut voor Toegepaste Geowetenschappen TNO.

Edelman, C.H., Eringa, L., Hoeksema, K.J., Jantzen, J.J. \& Modderman, P.J.R., 1950. Een bodemkartering van de Bommelerwaard boven den Meidijk. Verslagen van Landbouwkundige Onderzoekingen 56.18. De bodemkartering van Nederland, deel 7, p. 1-137.

Egberts, H., 1950. De bodemgesteldheid van de Betuwe. 's-Gravenhage: Verslagen van Landbouwkundige Onderzoekingen 56.19. Serie: De bodemkartering van Nederland, deel 8, p. 1-82.

Fisk, H.N., 1947. Fine-Grained Alluvial Deposits and Their Effects on Mississippi River Activity. In Two Volumes. Corps of Engineers, U.S. Army. Waterways Experiment Station, Vicksburg, Mississippi.
Hageman, B.P., 1963. De profieltype-legenda van de geologische kaart voor het zeeklei- en rivierkleigebied. Tijdschrift van het Koninklijk Nederlands Aardrijkskundig Genootschap, Tweede Reeks 80, pp. 217-229.

Koomen, A.J.M. \& Maas, G.J., 2005. Geomorfologische Kaart van Nederland $(\mathrm{GKN})$; Achtergronden bij het landsdekkende digitale bestand. Alterrarapport 1039.

Makaske, B., 1998. Anastoming rivers - Forms, processes and sediments. Ph. D. Thesis. Utrecht: KNAG/Faculteit Ruimtelijke Wetenschappen Universiteit Utrecht, Netherlands Geographical Studies 249, 287 p.

Pons, L.J., 1957. De geologie, de bodemvorming en de waterstaatkundige ontwikkeling van het Land van Maas en Waal en een gedeelte van het Rijk van Nijmegen. 's-Gravenhage: Verslagen van Landbouwkundige Onderzoekingen 63.11, Dissertatie Wageningen. Bodemkundige Studies 3, 156 p.

Pons, L.J., 1966. De bodemkartering van het Land van Maas en Waal en een gedeelte van het Rijk van Nijmegen. Verslagen van Landbouwkundige Onderzoekingen 646, De Bodemkartering van Nederland deel XXII, Stichting voor Bodemkartering, Wageningen, $129 \mathrm{p}$.

Rijkswaterstaat-AGI, 2004. Actueel Hoogtebestand van Nederland. Rijkswaterstaat, Adviesdienst Geo-informatie en ICT, Delft.

Rijkswaterstaat-AGI, 2005. Actueel Hoogtebestand van Nederland. Revised version. Rijkswaterstaat, Adviesdienst Geo-informatie en ICT, Delft.

Stiboka, 1965. De bodem van Nederland. Wageningen: Stichting voor Bodemkartering.

Stouthamer, E., 2001. Holocene avulsions in the Rhine-Meuse delta. Netherlands Geographical Studies 283, 211 pp. KNAG/Faculteit Ruimtelijke Wetenschappen Universiteit Utrecht.

Tesch, P., 1942. Toelichtingen bij de Geologische Kaart van Nederland. Mededeeling nr. 1: De geologische kaart van Nederland en hare beteekenis voor verschillende doeleinden. 's-Gravenhage, Algemeene Landsdrukkerij, 1942. Mededeelingen van de Geologische Stichting, serie D.

Törnqvist, T.E., 1993. Fluvial sedimentary geology and chronology of the Holocene Rhine-Meuse delta, the Netherlands. Ph.D. Thesis Utrecht University, KNAG/Faculteit Ruimtelijke Wetenschappen Universiteit Utrecht, Netherlands Geographical Studies 166, 176 p.

Van Heerd, R.M., Kuijlaars, E.A.C., Teeuw, M.P. \& Van 't Zand, R.J., 2000. Productspecificatie AHN 2000. Report nr. MDTGM 2000.13. Rijkswaterstaat, Adviesdienst Geo-informatie en ICT, Delft.

Vink, T., 1926. De Lekstreek, een aardrijkskundige verkenning van een bewoond deltagebied. Ph.D. Thesis, Amsterdam, H.J. Paris.

Verbraeck, A., 1970. Toelichtingen bij de geologische kaart van Nederland, schaal 1 : 50.000, blad Gorinchem 0ost (380). Haarlem: Rijks Geologische Dienst.

Verbraeck, A., 1984. Toelichtingen bij de geologische kaart van Nederland, schaal $1: 50.000$, bladen Tiel West (39W) en Tiel 0ost (390). Haarlem, Rijks Geologische Dienst, 335 p.

Weerts, H.J.T., 1996. Complex confining layers. Architecture and hydraulic properties of Holocene and Late Weichselian deposits in the fluvial RhineMeuse delta, the Netherlands. Netherlands Geographical Studies 213, 189 pp. KNAG/Faculteit Ruimtelijke Wetenschappen Universiteit Utrecht.

Weerts, H.J.T. \& Berendsen, H.J.A., 1995. Late Weichselian and Holocene fluvial palaeogeography of the southern Rhine-Meuse delta (the Netherlands). Geologie en Mijnbouw 74: 199-212. 